\title{
Hemispheric Travelers on the Rioplatense Stage ${ }^{1}$
}

\section{William Acree}

In mid-July 1886 Sarah Bernhardt finally arrived to Buenos Aires via Rio de Janeiro, where spectators eagerly awaited her presence at a limited number of functions. Bernhardt had just missed the debut of the Creole drama Juan Moreira, previously presented as a pantomime and now enhanced with talking characters. ${ }^{2}$ It would be easy to imagine the prima donna attending any number of forms of popular entertainment during her stay. Her arrival coincided with the new spectacles of the Carlo Brothers (a U.S. circus family) and Frank Brown (an English clown), while the Italian showman Pablo Raffetto put on an "unauthorized" version of Moreira every night. She could have attended a Spanish zarzuela or strolled through the Plaza San Martín to glimpse a Grand Panorama. Yet picturing Bernhardt at a performance of Moreira is the most fascinating to contemplate. Moreira was just her style. Moreover, the crossing of these two brought together trajectories going in opposite directions - that of hemispheric travelers on the Rioplatense stage, now on their downward slope, and one corresponding to all things Creole, shooting upward. In August, Bernhardt traveled north to Rosario for a set, down to La Plata for an appearance, and then over to Montevideo, where she completed her Rioplatense tour.

Bernhardt's South American tour (her first) obviously tells us something about her fearlessness to brave Transatlantic travel. But beyond this quality of her character, her time in the Plata river region reveals a rich entertainment market whose performers followed a circuit that was centered in Buenos Aires and Montevideo, included smaller towns along the tributary rivers leading to the Río de la Plata, and stretched as far north as Rio de Janeiro, which was often the connecting point for ships coming from Europe and the eastern U.S. By this time, however, this circuit and its corresponding entertainment market had been expanding for over half a century. 
More specifically, from the 1820 s up through the 1880 s, an increasingly widespread presence of Italian, French, and North American entertainers in Argentina and Uruguay offered musical and opera shows, engaged in the extravagant and the bizarre, and staged circus and equestrian spectacles that were especially successful in attracting crowds. While hemispheric travelers tried their luck throughout Latin America, the population concentration in the port capitals of Buenos Aires and Montevideo, as well as their relative proximity to each other and smaller towns, linked by an easily navigable river system, made this particular region an attractive destination. Performers could easily give shows in a dozen or more towns without having to travel very far at all. By the time they had finished a cycle (which could last from several months to a year), they could start over again with new offerings. Moreover, massive immigration to this area during the second half of the century resulted in rapid population growth. For hemispheric travelers this meant new potential audiences and chances for turning a profit, which was the logic that governed their movement. As this performance circuit took shape, with growing numbers of travelers, spectacles, and spectators, the scale of the entertainment marketplace grew impressively large.

Bernhardt's short stint in the region also points to the importance of hemispheric travelers as cultural intermediaries (Bourdieu; Negus; Nixon and Du Gay). In contrast to other types of travelers who chose to observe from a distance or who had little contact with local populations, the entertainers who traveled to the southern hemisphere were invested in connecting with their audiences. Their earnings and livelihoods depended on those bonds. Thus, the Italians Pablo Raffetto and Giuseppe Chiarini, both international ring leaders of sorts who contracted circus artists from three continents, performed in the region for years on end. The more cosmopolitan acts of illusionists, opera stars, and theatre icons like Bernhardt likewise served as the interface between new cultural spectators in the Río de la Plata and trends from afar. When such cultural intermediaries landed at a border post like Monte Caseros, Argentina, or the quiet Mercedes, Uruguay, the world literally came to town. Even in the more urban port capitals, cultural intermediaries exercised a powerful force of attraction, as displayed by the crowds who clamored to glimpse that embodiment of cosmopolitanism, Bernhardt.

Finally, as this article delves into the cultural geography of entertainment options that grew more dense by the decade, it will be crucial to keep in mind that hemispheric travelers ultimately did much more than entertain. They unwittingly anchored the Río de la Plata in a broader Atlantic World of 
entertainment flows (Roach). These travelers also ushered in a new emphasis on spectatorship. This feature of the half century in focus in this essay stands in marked contrast to the forms of royal ostentation, religious ceremony, and patriotic celebrations of the late colonial period and early republican years, all of which were highly participatory spectacles. Audiences continued to participate on occasion in performances after 1830 - wrestling an Italian Hercules or engaging in horse races with traveling equestrian artists, for example. Yet being a spectator became a defining element of this moment in the history of entertainment in the region.

\section{Diversiones públicas}

The last weekend of May 1878 was a busy one in Montevideo. Those looking to go out could choose from a variety of diversiones públicas, as papers by this time titled their sections announcing pastimes and public amusements. The city's new main theatre venue, the Teatro Solís, was offering a fairly standard group of operas - El Trovador and Faust - by the recently arrived Compañía Lírica Italiana. Those in a dancing mood could attend a ball from $10 \mathrm{pm}$ to $3 \mathrm{am}$, where señoras and señoritas, of course, had free admission. Somewhat more extravagant was the show at the Optical Museum and Magic Castle. Visitors were treated to "new diversions" with titles like "Evangelical Visions," "Purgatory," "The Terrible Last Day," "Horrific Hell," and "Glories of Heaven." Most outstanding among the choices, though, was Fish Man. "HE'S HERE!," proclaimed the ad for El hombre pez. "The celebrity of our time! The fixation of every audience! The inimitable FISH MAN!" Otherwise known as Mr. Watson, Fish Man acted with his sidekick siren and a handful of other guest artists as part of the English Hadwin and Williams Equestrian show, successful across the region (El Siglo 24 May 1878).

The choices open to Montevideans that weekend reveal several characteristics about the diversiones públicas in the Río de la Plata. To begin, the variety of options was impressive for a city of just over 100,000. Yet similar lists can be found for Montevideo as well as Buenos Aires throughout the 1870 s and, to a slightly lesser extent, 1860 s, when the category of diversiones públicas began appearing with frequency in the region's press. As entertainment options multiplied during the second half of the century, there was a need to establish a separate publicity space that corresponded to the growing place that entertainment had in people's lives and local economies. Second, hemispheric travelers are the heart of these public diversions. Two types of these - opera and formal theatre, on one hand, and what I will call 
the extravagant or bizarre spectacle on the other-are especially illustrative in this regard.

The first opera performers arrived in the region in the 1820s. Though their functions received a fair amount of publicity, the quality of opera performances was far from uniform, with many missed notes being a hallmark especially of the earlier years. Opera shows took place in Montevideo's Casa de Comedias and the Coliseo Provisional in Buenos Aires, where people often went more to engage in the favorite pastime of social gazing than to enjoy the musical and dramatic acts. While opera numbers were geared for small (elite) sectors of the region's population, popular classes were also in attendance, as complaints about the "excess of people of color" and others on foot occupying the doorways and halls of the Casa de Comedias attest (Myers 124; Klein 27). That said, opera was a natural source of hemispheric travelers to the region. Ironically, opera helped fill an entertainment gap that was left by a decline in bull fights in the late 1810s and 1820s (Rojas).

Prior to steamship travel in the mid-1800s, few opera singers ventured as far south as the Río de la Plata. Many of those who did brave the voyage were unable to land lead roles in Europe and decided to try their luck abroad (Roselli). Others came as guests of the Brazilian Emperor to Rio de Janeiro and then took advantage of the relative proximity to Buenos Aires and Montevideo (Rosselli). Julieta Anselmi and her daughter, for example, arrived in early 1823 to Buenos Aires from Rio de Janeiro and joined with musicians to put on shows during Lent (Klein 37). The chronicler Manuel Bilbao wrote about the Barber of Seville being performed at the Coliseo Provisional in Buenos Aires in 1825 and a mix of local performers teaming up with European artists to stage lyrical numbers during the late 1820s (205-206). The ubiquitous Isidoro de María likewise wrote of Italian and Spanish singers who gave several monthly performances at Montevideo's theatre around 1830, of acts from plays like Othello, and of pantomimes and sainetes that added life to intermissions or bid farewell to audiences. De María also comments that these performers enjoyed success on both sides of the Plata river (Montevideo 225-31). A handful of local theatre favorites even emerged in these early years - Trinidad Guevara, the Afro-descendant Luis Ambrosio Morante, Felipe David, Fernando Quijano, and Juan José Casacuberta (Castagnino, El teatro, vol. 1: 77-117, 145-68; Borucki). Yet from the late 1820 s through the 1850 s, consistent success at the box office was not a regular feature of the theatre or opera in the entertainment market (Castagnino, Literatura 45-62). Limited infrastructure was in part to blame, 
but the slow start of such entertainment owed as well to the political climate of the 1830s and 1840s and, as will become clearer below, state support of circus activity.

Travel narratives from these years register complaints about the limited fare. One Englishman told his readers that "The theatre at Buenos Ayres is a neat building, but I only visited it once, as I did not understand the language; it then appeared well-attended. Horse-racing and cock-fighting were [...] the most prevalent diversions amongst the natives" (Haigh 27-28). This writer's more linguistically capable compatriot, William Parish Robertson, was thoroughly unimpressed with the theatre's design. The cast (save the European members) and interior décor left much to be desired in his mind, especially compared to London's offerings. But, he admitted, some of the locals thought very highly of their theatre (Robertson 123-24). Uruguayan author Antonio Pereira noted that French and Italian opera companies- the same ones who made occasional appearances across the river-played in Montevideo's theatre, despite the siege of the city throughout the 1840s. These traveling performers only offered opera fragments or abbreviated concerts during the 1840s. A Chilean visitor to Buenos Aires in 1855 continued to complain about the lack of variety at the theatre. There is an "okay" company, but all they really do, he lamented, is put on sainetes. So most of the time he chose instead to attend opera to flirt with porteñas in the cazuela (Vicuña Mackenna 41-43).

In the 1850s, however, after the end to two decades of civil war that had gripped the region, opera and formal theatre productions slowly began to gain momentum. New performance venues that had been designed, but whose construction was on hold due to the prolonged state of war, came to fruition. The Teatro Solís in Montevideo opened its doors in 1856, with Buenos Aires's first Colón Theater following suit the next year, both with full-scale operas and star power. Hemispheric travelers, from Italy to be precise, gave the inaugural performances. In fact, the headlining female vocalist in Montevideo took the same role in Buenos Aires (Salgado; Llanes 29-30). Investors and politicians who supported the building of these premier spaces subscribed to the old idea of the theatre being an educational site, one that would reflect the "enlightened stature" of their society, or help citizens achieve that state. Supporters recognized as equally important the function of these new venues to promote a "strong sense of association" (de María, El teatro; Sarmiento). That the Solís and Colón were built as part of each city's central core was crucial to promoting them as social gathering places. 
The increase in the number of shows as well as the development of additional performance spaces in the 1860s and 1870s helped in this respect. This was especially true after the end of the gruesome Paraguayan War (18641870). These two decades saw provocative shows like a dramatic rendition of Uncle Tom's Cabin and visits of prominent figures like the pianist Louis Gottschalk, the Italian actors Adelaide Ristori and Ernesto Rossi, and Eleonora Duse, one of Sarah Bernhardt's rivals who performed at the Politeama before Sarah (La República 7-8 Oct., 13 Nov. 1861).

Audience reactions were seemingly positive to the surge in these sorts of performance groups from abroad. Gottschalk gloated about being "everywhere successful, everywhere fêted... making his life a complete ovation" while touring Buenos Aires, Montevideo, and other points in South America in the late 1860s (71). Similarly, Ristori writes in her autobiography of her second trip to the Americas, arriving in Rio de Janeiro in June 1869. She relates that crowds loved her in Rio, and that the emperor honored her with a "special" friendship. By September, Ristori was performing in Buenos Aires. "Fresh joys awaited me in that pleasant land, where the numerous Italian colony [...] gave me a truly royal welcome, almost as though they were jealous of that offered me by the people of the Argentine Republic." Her stay in Buenos Aires was profitable enough for her to remain through the end of October, before heading to Montevideo and "obtaining the same results" (103-104, 109). One reviewer of Ristori celebrated her role in Giaconda, saying that it left impressions that "won't disappear from the memory of the Buenos Aires public" (Estrada 359-60). Manuel Bilbao remembered that Ristori "moved her audience to laughter and tears" (210). In Montevideo she had a similar effect. Antonio Pereira, who attended all of her shows, praised her "perfection" and that of similar performers from France and Italy (31011; Bilbao 222-37).

So while crowds attending theatre and opera performances may or may not have understood their experience as educational, they clearly appreciated the entertainment and social value of being there. Impresarios like César Ciacchi (who promoted the Carlo brothers' circus bashes, Bernhardt's Rioplatense visit, and every type of spectacle in between) wanted to capitalize on this fact in addition to marketing the latest European artists who, in the words of the contemporary cultural commentator Santiago Estrada, were "raising the stages of Buenos Aires [and Montevideo] to the same level as the best theaters of the Old World" (232). Estrada was talking about one of the desired impacts of cultural intermediaries. ${ }^{3}$ 
From the 1830 s through the 1880 s there was also a growing stream of travelers who presented optical illusions, constant surprise, and exaggeration. Such shows often involved a dose of swindling or craftiness, in addition to genuine creativity. They enjoyed high audience turnout and overlapped regularly with opera and theatre offerings, occasionally peeling away spectators from these. Similar to the world of opera, prestidigitators, illusionists, "professors" of occult sciences, and other stunt artists or practitioners of the bizarre who ended up in the Río de la Plata were primarily European. While their shows did include audience participation, they were largely spectacles meant to be watched (preferably with amazement). And like Bernhardt and so many others, these practitioners of the extravagant set out on international tours in hopes of making a buck (Fernández). Some did strike it rich and return home. Others wandered around South America in search of new audiences or fleeing from accusations of being thieving charlatans. As with opera and formal theatrical productions, the number of these more popular forms of entertainment increased dramatically after 1860 .

An early example of this type of performer was the famous Stanislas, the Franco-North American master of tricks and prestidigitation who roused audiences in the region in 1824-25 (Wilde 52). Many others were soon to follow, and with similar success. Take the Swiss "professor of physics" and self-proclaimed magician Pedro Latzon, who also went by the name Mr. Nelson. Latzon had given his most provocative number in Montevideo in 1829 before taking it to Buenos Aires. It was the classic "decapitating act," with the subsequent resurrection of the victim, which he and others would repeat in the following decades (Klein 200). In the early 1840s another "professor of physics and ventriloquism," George Sutton, attempted to impress audiences in Montevideo and Buenos Aires. Members of the press covering this English prestidigitator's shows accused him of "promising much, but making good on very little" (qtd. in Klein 200).

More warmly received was a company led by Monsieur Robert and his wife, from France, who remained active in the region for close to twenty years. An advertisement for one of their performances in November 1842 gives a sense of what made their shows appealing. The evening opened at $8 \mathrm{pm}$ with a performance of a full orchestra, which gave way to the show's three main parts. Part one: a short comical act. Part two: an "hour of magic" with Monsieur Robert himself headlining the act. He wowed the crowd with his "creative physics, sleight of hand, disappearances," and the like. The third part of the evening's show, however, was the most action-packed. Robert was 
again on center stage, juggling china. He followed this with a knife-wielding display and "various tricks that words cannot express." Next came a dance where dancers launched fireworks from their fingers and toes. Spectators then laughed at two dogs dressed in royal attire who walked around on their hind legs, and marveled at Robert's balancing of "five rifles stacked in a pyramid whose weight rested on one bayonet poised on Robert's teeth." The show concluded with the patriotic hoisting of the national flag, with a young boy perched on the end of the flag pole for comic relief (Lusnich and Llahí 363). ${ }^{4}$ The local paper The British Packet commented that the show was sold out despite ticket prices that went for double the normal rate (Castagnino, $E l$ teatro, vol. 2: 287-90; 418).

With music, dance, magic, and a touch of the bizarre, the Robert Company attempted to pack in attractions for a variety of spectators. Similar shows could be seen at new venues in the 1830s and 1840s, such as the Jardín del Retiro and the Teatro de la Federación in Buenos Aires, plus outdoor spaces across the region where performers threw up tents. Not all, however, were as beloved as the Roberts. The Cañete husband and wife duo were jeered repeatedly. Then there is the example of Antonio Leroux, another French prestidigitator who was far from impressive. Audience members demonstrated regularly their dissatisfaction with his shows. Rather than trying to address the complaints by modifying his numbers, one night in April 1845 Leroux stopped his performance to insult the public and was subsequently imprisoned (Castagnino, El teatro, vol. 1: 134-36, 290-91).

Aside from becoming more numerous in the last third of the century, spectacles of this nature grew increasingly extravagant. Rafael Scalli, a.k.a. the Italian Hercules (a stage name several such figures adopted), spent a month in Montevideo in 1863. He set up in a tent in front of the Teatro Solís, where ticket holders were treated to a multi-part show. There were displays of human strength, with Scalli lifting enormous weight or gripping a ladder while two horses tried to pull him free. There were arias from Italian operas. And then the main event had Scalli wrestling foes, initially from his company, followed by volunteers from the crowd (El Siglo 10 Mar.-5Apr. 1863). Prestidigitators traveled from town to town, staying as long as they could maintain a following. Some of these were amateurs, like a fifteen-year-old in Buenos Aires or disciples of renowned figures in the field. Such was the case of Teodoro Trua, an African prestidigitator who delighted his public in spite of excessive summer heat in the border town of Monte Caseros, Argentina, after having been in Asunción, Rio de Janeiro, Buenos Aires, Montevideo, and 
somewhere in Bolivia. A review of one of Trua's benefit shows for the town's public school underscored audience enthusiasm. The ballroom where he performed filled initially with "families, respectable matriarchs, and distinguished young women of our society. Then, all of a sudden, a wave of rough-looking bearded guys took over the remaining seats" (El Nacional, 28 June 1864; 3 Nov. 1865; El Porvenir, 28 Feb.-10 Mar. 1886). As much should have been expected, though, given that Trua was the only cultural intermediary, not to mention the only show, in town at the moment. The masters themselves came, too, like the French duo Carl and Alexander Hermann (the Great Hermann), who enjoyed repeated success in Brazil, Argentina, and Uruguay in the 1870s and 1880s. ${ }^{5}$ All of these shows, from Scalli to Hermann, appealed to crowds by defying logic and selling the never-before-seen, often at a bargain for families - children usually benefitted from half-price admission.

An extensive list of others defied gravity. The Great Spalding and Rogers Oceanic Circus were early innovators here. At the end of March 1863 they announced that, while most of the company would leave Montevideo for Rio Grande do Sul, guest actors from France - the Buislay family - and other company members had prepared a few special events at the Teatro San Felipe. There spectators could enjoy the Zampillaerostation — or flying trapeze - and the trademark Buislay stunt called the Niagara Falls jump. Writers for El Siglo describe the move in detail. "Picture a man plunging from the upper-most gallery of the theater, covering the distance from there to the stage, and then catching himself by his legs on a trapeze. This was José Buislay. From there, he swings up to the ceiling where he holds another trapeze with his arms of steel. Then, his brother Julio launches himself in the same manner, catching hold of the trapeze José is tending, only to let go and grab onto José's legs at the last instant as the crowd gasps with relief. They would continue were it not for the audience breaking into a wild applause and screaming 'Enough!'” (15 Mar.-9 Apr.).

On the heels of prestidigitators and acrobats like the Buislays came a final cohort of extravagant hemispheric travelers who were crafty and creative charlatans often selling themselves as professors of the occult and changing their identities. There is no better illustration of this strand than the mysterious Conde de Dás (as he was most often called), who began crisscrossing the Río de la Plata around 1890 during his multi-year stint in Latin America. The Count had come to Buenos Aires from Spain (where he allegedly was in such debt that his return was prohibited). In Buenos Aires he and his "wife" established a "Lodge for Occult Studies." When the Lodge was denounced 
in the press for exploiting the good faith of porteños who had signed up for membership, Dás wrote a letter blaming everything on his hustling wife, and took off for somewhere in Brazil (La Prensa, 20 Mar. 1894; El Comercio, 25 July 1894). In 1895, though, Dás turned up again in Uruguay, where he and his spouse (most likely the same woman) performed shows with programs like the following. Part one: the importance of the occult and the power of will; part two: a demonstration of things ranging from astral perception (the activity consisted simply of "painting blindfolded") to helping a plant to germinate in less than ten minutes; part three: telepathy and other acts of "second degree occult sciences" (El Paysandú, 28 Mar. 1895). They received a warm reception in Montevideo, a harsh critique in Salto, and a weak turnout in Paysandú (Centro Gallego; Ecos del Progreso, 23-27 Mar. 1895; El Paysandú, 21 Feb., 28 Mar., 1-8 Apr. 1895). In the smaller town of Mercedes, though, there was a more positive showing. The local paper reported that the theatre was full for both showings and that the audience was "completely satisfied" with the display of telepathy and other "most interesting phenomena." Some spectators, however, "seemed to harbor skepticism of Dás's act" (El Departamento, 17, 22 Apr. 1895). People began to doubt everything about the Count, from his medical title to his claim to have studied fakirism in India to his motives (Finch). This palpable doubt led the count to move frequently from venue to venue. But he continued his travels, returning to Buenos Aires again — where spectators booed, played with the lighting at the theatre, and threw chairs onto the stage during the plant-growing number-before attracting attention and creating scandals elsewhere (Caras y Caretas).

Of course the scope of the entertainment market was closely tied to the demographic transformation that the region experienced in the second half of the 1800s. Massive waves of immigrants, with Italians and Spaniards being the most numerous, doubled, tripled, and quadrupled populations in short time spans. Newcomers fueled the urbanization of Buenos Aires, Montevideo, and smaller cities located nearby. They also constituted a massive new group of entertainment consumers. A few municipal and national census numbers put this population growth in perspective. In Buenos Aires Province, immigrant figures rose from around 150,000 in 1869 to some 284,000 in 1895, accounting for roughly 30 percent of the provincial population. In the city of Buenos Aires, which was tallied separately in the second national census (1895), immigrants made up more than half the population of 664,000. Similarly, in the department of Montevideo, the immigrant population swelled from 27,000 
in 1860 to more than 100,000 in 1889 , hovering between $40-50$ percent of the total number of departmental residents (Silva; Arteaga).

Thus far, then, we have seen the gradual growth of opera and formal theatre, as well as more extravagant spectacles, thanks to cultural intermediaries who traveled to the Río de la Plata over the course of half a century. The proliferation of these modes of entertainment in the 1860s generated a more prominent place for diversiones públicas in daily social life. These spectacles emphazized spectatorship and were meant to wow, amuse, and entertain audiences. Thanks to the rapid population growth there were plenty of new spectators. Two other staple public diversions developed with strong influence from hemispheric travelers from the 1830s on: the circus and the equestrian show. These forms of entertainment stand out for their close relationship in comparison to other modes of spectacle, and for the deep, sustained impact they would exercise in the region.

\section{Circus and Equestrian Marvels}

Horseplay - literally - had long been a feature of the region's entertainment options. Generations had lived on horseback, so to say, and they appreciated displays of horsemanship. It was in part for these reasons that circus and equestrian shows not only took horseplay to new levels of commercial success; they also resonated widely with audiences in the region. There was a local feel to seeing men and women show off their equestrian talents. Contributing to this local character were locals themselves. Hemispheric travelers who mounted circus and equestrian marvels no doubt fit the pattern traced thus far. But in contrast to opera or theatre groups, traveling circus troupes readily incorporated local "artists" into their productions and attempted to "fit in" to the local socialscape from early on. Moreover, these groups offered variety at their shows (acrobatics, daring stunts, horseplay, and pantomime) and advertised them as something for everyone, helping to position these diversions as the most widely attended through the early 1880s. The abundance of examples of circus and equestrian performances can be overwhelming, so this section follows a handful of emblematic ones.

Touring circus and equestrian acts started arriving sporadically in the region in the $1810 \mathrm{~s}$, and by the mid-1820s they were already standard entertainment fare, although the frequency of performances was limited. Three groups developed a following on both sides of the river during the first couple decades of circus and equestrian shows. Francis Bradley led one of these groups. Bradley was an all-around circus man — clown, jockey, rope 
walker, and an expert with fireworks. He joined forces with other Englishmen in Buenos Aires and became the director of the city's first "Circo Olímpico," despite repeated stints in jail for daring to drop his trousers and engaging in other shenanigans (Klein 45-48; Seibel 20). In the late 1820s Bradley formed part of other circus groups, where he made popular the pantomime El rústico borracho. As one can imagine, the story was simple: an inebriated man tried and tried to mount a horse, with no luck - and it elicited waves of laughter (Klein 49). What Bradley introduces to the scene, in addition to the circusequestrian spectacle, is the multi-talented circus performer.

José Chiarini led another group in the 1820 s and 1830 s, the first to hold a profitable season at the new Parque Argentino in Buenos Aires, opened in 1829, where they stayed for five months. Italians, like Chiarini and his family, and Spaniards made up most of the group, though there were a couple known Uruguayan performers, too, like Fernando Quijano (Bosch 158-59). Chiarini and company moved back and forth regularly between Buenos Aires and Montevideo. So after their success at the Parque Argentino, they were in Montevideo for the festivities surrounding the swearing in of the constitution on 18 July 1830. In addition to the dances, rifle salutes, and displays of dexterity on horseback, the program included Chiarini, who "will execute all types of maneuvers on the tightrope" spanning the square where events unfolded. ${ }^{6}$ Following Chiarini's participation in these patriotic ceremonies - an important early, state recognition of the social value of popular spectacle - the group traveled north to Brazil, where they performed in Rio Grande, Minas Gerais, and Rio de Janeiro (Seibel 20-22; Klein 123-27).

The third group to develop a following in the Plata in these years was the Laforest Smith equestrian and acrobatic company, which had arrived in Montevideo from Boston. They gave performances in Uruguay from October 1833 through May 1834, and then in Buenos Aires beginning in June that year. Like Chiarini, Laforest recruited local talent to fill out his troupe. And similar to Bradley, Laforest was good at many circus numbers. He had his own special stunt horse that did all sorts of equine maneuvers, including finding objects that a clown would hide from the animal. A real crowd pleaser that Laforest gave was an act where he dressed and undressed himself in a variety of men's and women's outfits, all while on horseback. Laforest Smith stayed in the city over a year before apparently going bankrupt, a testament to the popular, yet vulnerable roots that circus and equestrian acts had established in these years (Klein 127-32; Castagnino, El circo 28). 
With the nomination of Juan Manuel de Rosas as head of the Federalist party and governor of Buenos Aires province in 1829, the circus received a burst of state support, linking popular spectacle with populist statecraft for the next two decades. This was the moment when politics were closely tied to performance, more so than at any other point through the $1880 \mathrm{~s}$. Theatre spaces were routinely used to hold government balls and other Federalist celebrations, while the official backing of circuses helped assure audiences at these spectacles. When Rosas returned to the governorship in 1835 after a brief hiatus, his first entertainment outing was to the circus. Beginning in 1835 entertainment programs displayed a sort of masthead with the Federalist slogan - "Long Live the Federalists! Death to the Savage Unitarians!" In 1841 one illusionist and professor of physics performed a stunt in which a Federalist slit the throat of a "savage Unitarian." A shift in audience makeup occurred in this period, too, with Unitarian families who were theatre patrons during the early 1830 s emigrating toward the end of the decade. The result was that from the mid-1830s through the early 1850 s the circus was the premier amusement in Buenos Aires, while theatre underwent what some have called with obvious negative connotations a process of "plebianization" (Castagnino, El teatro, vol. 1: 267-86; vol. 2:404-77). Similar politically charged details feature heavily in Uruguayan entertainment of the same period. The circus gained traction in interior towns that fell within the domain of Rosas's counterpart, Manuel Oribe. In contrast, the liberal holdout of Montevideo did not experience the same pervasive influence of these characteristics as Buenos Aires. The fall of Rosas and Oribe in 1852 lead to a quick dissolution of such direct connections between the circus and state politics.

Lack of state backing did not dent the popularity of the circus, though. In fact, circus and equestrian activity gained in both momentum and stability in the decade of 1860 and flourished up until the time of Sarah Bernhardt's visit. Consider the Spalding and Rogers Great Ocean Circus (they had hosted the high-flying Buislay brothers), whose success in the early 1860 s yields insight into several elements behind the circus expansion. Four principal circus troupes from the U.S. comprised the group. These arrived in Buenos Aires in late 1862 on the company ship (the group had its own vessel refitted for its South American tour), direct from Rio de Janeiro (The Standard, 25 Nov. 1862). Within a week of landing in Argentina they were advertising daily shows, with special prices and show times for families on Sundays to allow for children to be in bed early. Everything about the Spalding and Rogers outfit heralded the expanded scale in this type of entertainment. In addition 
to the extensive cast, the company brought a portable amphitheater with a capacity for 1,500 (The Standard, 14 Dec. 1862; El Siglo, 4 Feb. 1863). In January 1863, before departing Buenos Aires for Montevideo, the company added a "Chinese Festival" to conclude each performance, apparently with Chinese performers now forming part of the cast (The Standard, 18 Jan. 1863). In Montevideo the ticket sales for the company's shows at the amphitheater, erected in front of the Solís and the presidential palace, routinely surpassed the Solís sales in February and March (El Siglo, 21-24 Mar. 1863).

Dozens of other hemispherically renowned troupes followed the Spalding and Rogers group and consisted of a similar makeup. The Lee Brothers filled the immediate gap left by the Ocean Circus. Then came the Nelsons, and Nathaniel Rogers and friends. Rogers had first arrived in the region as a contract performer with Spalding and Rogers. After separating from the company, he spent several years roaming South America and living off the shows he gave. All of these performers were from the U.S., where many had worked together previously, were related, or at the very least knew of the others' reputation. One of the most outstanding features in the rise to the top of circus and equestrian spectacles during these years is the enduring presence and wide circulation of U.S. circus families. The search for more peaceful lands as the Civil War flared was one explanation for the stream of U.S. performers. European groups like the English Courtney and Sanford Circus and the Italian Circo Casali poured into the Plata, too (El Nacional, 30 Apr. 1873; 10 Dec. 1873). Like the Spalding and Rogers company, these others subscribed to what would become defining features of the zenith of circus and equestrian marvels. This meant catering to audience desires, cozying up to local officials through benefit shows, producing spectacles with increasing fanfare, selecting centrally located performance sites, and engaging in elaborate marketing, such as detailed advertising in the local press, free admission for theatre reviewers or people of influence, and the announcement of "final shows" to drum up attendance,.

Among these participants in the heyday of circus and equestrian activity, three groups that traveled around the region the longest, that exercised the greatest impact on the course the entertainment market would take, and that made possible Bernhardt's potential meeting with Moreira, were the Carlo Brothers, Giuseppe Chiarini's Circo Italiano, and brilliant entertainment entrepreneur Pablo Raffetto and company.

The Carlos first arrived in Montevideo in June 1869 with Giuseppe Chiarini, son of the Chiarini mentioned above. Chiarini teamed up with the 
Carlos regularly in San Francisco in the 1860s. After a whirlwind tour that had taken Chiarini's Circo Italiano from San Francisco to Mexico to Cuba, then down to Lima, Valparaíso, and Santiago, they arrived in Montevideo, where they performed for some five thousand people at their debut show (Daily Alta California, 18 Nov. 1864, 25 May 1868; 5 Sept., 27 Nov. 1872; Klein, 205-06). By August, this "company without rival in the Americas" was "causing a frenzy" in Buenos Aires, where they would perform equestrian tricks, acrobatics, and pantomimes every day and twice on Sundays through the end of October. Chiarini's Circo Italiano was a big affair, with disciples of Chiarini such as the young English phenom Catalina Holloway and the "ebony butterfly" Belén Cuba, as well as a host of other virtuosos including the Carlos" "sumptuous uniforms" that Chiarini had purchased in Mexico City (these had been left behind by the Emperor Maximiliano) and dozens of horses from Spain, Italy, Cuba, Mexico, and the U.S. (El Nacional, 5 Aug.-23 Oct. 1869). In a comical introduction of formal theatrical elements, Chiarini himself rode "Othello," among other horses, while Romeo and Juliette - two Brazilian mules - became regular characters at the show (El Nacional, 19, 28 Aug. 1869; 8, 20 Sept. 1869). For the next two decades, Chiarini and Carlo family members were in and out of Buenos Aires, Montevideo, and smaller towns in the interior, working together at times, as well as separately.

The Carlo family (George, Henry, Amelia, William, and Frederick) established quite a reputation apart from the Circo Italiano. In part, this celebrity stemmed from their extended performance runs in the region, beginning in 1869 and lasting into the mid-1880s. The Carlos employed lots of local performers (other circuses would later hire some of these "former Carlo Company actors" to boost ticket sales) as well as international talent (El Paysandú, June 1895). The English clown Frank Brown, with whom the family had toured the U.S., became a star in the Plata and definitely enhanced the group's acclaim (Castagnino, El circo criollo 106; El Mosquito, 6 Apr. 1884). Even more influential for their reputation was the Carlos' collaboration with the young Podestá brothers, who were making a name for themselves thanks largely to Pablo Raffeto.

Nicknamed the Genoese Barnum, Raffeto had made his way to Buenos Aires at the end of 1869 , too. Though his initial fame came from being a real hulk - challenging audience members to wrestling matches and always winning, or occasionally taking to his show a bear he trained to wrestle - he branched out to perform all varieties of circus tricks and to direct his own companies (Castagnino, El circo criollo 40-49; La Patria Argentina, 6 Mar. 
1884). Like Chiarini and the Carlo family, Raffeto became a sort of permanent itinerant Rioplatense entertainer, creating new content and opening theatres in Buenos Aires, Rosario, and Santa Fe through the early 1900s. And like the Carlos, Raffeto worked with his wife and children. Raffeto hired the Podestás - a Uruguayan circus family - to flesh out his team at the end of the 1870s. They had met outside of Montevideo in 1877, and for the next five years they worked on and off together in both Uruguay and Argentina, before they would become competitors.

It was the more immediate competition, though, from the Carlo Brothers and their employment of the Podestás in 1884 that set things in motion for hemispheric travelers and Creole passions to cross paths. In March of the same year the Carlo family was back in Buenos Aires. They gave daily shows Monday-Saturday, and two on Sundays, at the Politeama Argentino. And while crowds continued to fill the stands, the company looked for new ways to maintain audience enthusiasm. This was especially the case after mid-April, when a competing circus set up a few blocks away at Raffetto's new space. This new circus included José Podestá in what had become his signature role up to that point, the poet-clown-payador Pepino 88. The Carlos fought back. They offered a toy lottery for children, staged pantomimes, had monkeys ride Shetland ponies in a steeplechase, and held benefit shows that promised all new repertoires for local authorities and organizations (El Mosquito, 27 Apr. 1884; La Patria Argentina, 16 May 1884). Then, the day after they announced their last functions at the end of June, by which time they had given more than 100 shows in the city, came the news of the Podestás on the Carlo Brothers' program. Little Pablo showed off his acrobatic talents on the flying trapeze, Juan and José (a.k.a. Pepino) did a type of Niagara Falls Leap, and Pepino added his classic songs and humor. The true innovation, however, to the final shows that the Carlo team staged was the theatrical adaptation of Juan Moreira, without words. Moreira succeeded in livening up the last thirteen performances in Buenos Aires, with José Podestá as Moreira (La Patria Argentina, 4 Mar.-13 July 1884). After all, he could ride a horse, manage a facón, and improvise on the guitar, everything that was needed to look the part. Three to four thousand attended each of these last shows at the Politeama, after which the Carlos and the Podestás took their act to Rio de Janeiro.

To conclude, thanks to hemispheric travelers, a performance circuit began taking shape in the Río de la Plata in the 1830s and became more standardized in the second half of the century. Whether they set out to be 
cultural intermediaries or not, these travelers put spectators in touch with far-away worlds. The consolidation of this performance network and the increased number and variety of spectacles reveal the development of an entertainment market whose scale was quite dizzying by the $1880 \mathrm{~s}$, and in which spectatorship took the place of participation. For spectators, attending the offerings of this market at times provided a respite from war or, at others, a moment of family fun. When crowds stepped into the theatre throughout the 1840s to watch Monsieur Robert balance rifles on his teeth, when they stepped into the Spalding and Rogers portable amphitheater in the 1860s, or when they stepped into a Carlo family equestrian blowout, they stepped out of ordinary, daily time. The same was true of attending one of Bernhardt's limited performances. All of these spectacles on the Rioplatense stage gave viewers a Turnerian liminal experience, a time out of time, where imaginations roamed freely and greased the wheels of social interaction (Turner; Huizinga 1-46).

\section{Washington University in St. Louis}

\section{Notes}

1 I am grateful to LATR's readers for their insightful comments that helped me improve this article. My sincere thanks as well to colleagues and students in UC Berkeley's department of Spanish and Portuguese and UT Arlington's departments of Modern Languages and History for the chance to present and discuss portions of this essay. I also thank Christopher Conway and Matthew Karush for reading drafts and asking productive questions.

2 On Juan Moreira see Legrás and Mandressi.

3 The resulting mix of touring artists playing for immigrant and local audiences in the Plata led to what Roger Mirza characterizes as a "polyphonic theater system."

4 Ad from Archivo General de la Nación, Fondo y Colección José Juan Biedma 1126.

5 Bilbao 217; El Mosquito, 2 Dec. 1883; El Negro Timoteo 23 Dec. 1883; Ecos del Progreso, 29 Mar. 1884; Selgas 307-17.

6 Museo Histórico Nacional (Uruguay), Lavalleja, Impresos Col PBA, Programa Jura de la Constitución.

\section{Works Cited}

Arteaga, Juan José, et al., "Inmigración y estadística en el Uruguay, 1830-1940." Inmigración y estadisticas en el cono sur de América. Ed. Hernán Asdrúbal 
Silva. México, D.F.: Instituto Panamericano de Geografía e Historia; Washington, D.C.: Organización de los Estados Americanos, 1990. 261-372. Print. Bilbao, Manuel. Buenos Aires desde su fundación hasta nuestros días. Buenos Aires: Imprenta de Juan A. Alsina, 1902. Print.

Borucki, Alex. "Tensiones raciales en el juego de la representación. Actores afro en Montevideo tras la fundación republicana (1830-1840)." Gestos 42 (2006): 33-56. Print.

Bosch, Mariano G. "Viejos circos porteños: los bailes pantomímicos." Boletín de Estudios de Teatro 2.6 (1944): 157-61. Print.

Bourdieu, Pierre. Distinction: A Social Critique of the Judgment of Taste. Cambridge: Harvard U P, 2010. Print.

Caras y Caretas (Buenos Aires) 22 December 1900.

Castagnino, Raúl H. El circo criollo: datos y documentos para su historia, 17571924. Buenos Aires: Lajouane, 1953. Print.

. Literatura dramática argentina, 1717-1967. Buenos Aires: Editorial Pleamar, 1968. Print.

. El teatro en Buenos Aires durante la época de Rosas. 2 vols. Buenos Aires: Academia Argentina de Letras, 1989. Print.

Centro Gallego (Montevideo), pamphlet, 19 March 1895.

Daily Alta California (San Francisco).

de María, Isidoro. Montevideo Antiguo, vol. 1. Prolog. Juan E. Pivel Devoto. Montevideo: Ministerio de Instrucción Pública y Previsión Social, 1957. Print. . El teatro Solís: reseña histórica en el vigésimo noveno aniversario de su inauguración. Montevideo: Tipografía José Pedro Varela, 1885. Print.

El Comercio (Lima).

El Departamento (Mercedes, Uruguay).

Ecos del Progreso (Salto, Argentina).

El Mosquito (Buenos Aires).

El Nacional (Buenos Aires).

El Negro Timoteo (Montevideo).

El Paysandú (Paysandú).

El Porvenir (Monte Caseros, Argentina).

El Siglo (Montevideo).

Estrada, Santiago. Teatro: colección de artículos. Critical and biographical study by Antonio Peña y Goñi. Barcelona: Imprenta Henrich y Cía., 1889. Print.

Fernández, Mauro A. ("Fénix"). Historia de la magia y el ilusionismo en la Argentina: desde sus orígenes hasta el siglo XIX inclusive. Prolog. Teodoro Klein \& a "prólogo mágico" by Ricardo "Fantasio" Roucau. Buenos Aires: n.p., 1996. Print.

Finch, Laura I. “All about 'Rama." The Annals of Psychical Science 6 (1907): 426-34. Print. 
Gottschalk, Louis Moreau. Notes of a Pianist, During his Professional Tours in the United States, Canada, the Antilles, and South America. Ed. Clara Gottschalk. Trans. Robert E. Peterson. Philadelphia: J.B. Lippincott \& Co., 1881. Print.

Haigh, Samuel. Sketches of Buenos Ayres and Chile. London: James Carpenter \& Son, 1829. Print.

Huizinga, Johan. Homo Ludens: A Study of the Play-Element in Culture. Boston: The Beacon Press, 1955. Print.

Klein, Teodoro. El actor en el Río de la Plata, vol. 2. De Casacuberta a los Podestá. Buenos Aires: Ediciones Asociación Argentina de Actores, 1994. Print.

La Patria Argentina (Buenos Aires).

La Prensa (Buenos Aires).

La República (Montevideo).

Legrás, Horacio. "Palimpsesto, cultura popular y modernidad política en el Juan Moreira teatral." Latin American Theatre Review 36.2 (2003): 21-39. Print.

Lusnich, Ana Laura, and Susana Llahí. "El circo y las formas parateatrales." Historia del teatro argentino en Buenos Aires, vol. 1, Período de la constitución del teatro argentino (1700-1884). Ed. Osvaldo Pellettieri. Buenos Aires: Galerna, 2005. 358-64. Print.

Llanes, Ricardo M. Teatros de Buenos Aires: referencias históricas. Buenos Aires: Secretaria de Cultura y Acción Social, 1968. Print.

Mandressi, Rafael. "La nación en escena: notas sobre el nacionalismo teatral en la historiografía uruguaya del teatro." Latin American Theatre Review 29.2 (1996): 147-64. Print.

Mirza, Roger. "Para una revisión de la historia del teatro uruguayo: desde los orígenes hasta 1900." Uruguay: imaginarios culturales. Desde las huellas indigenas a la modernidad. Eds. Hugo Achugar \& Mabel Moraña. Montevideo: Ediciones Trilce; Pittsburgh: Instituto Internacional de Literatura Iberoamericana, 2000. 179-99. Print.

Myers, Jorge. "Una revolución en las costumbres: las nuevas formas de sociabilidad de la elite porteña, 1800-1860." Historia de la vida privada en la Argentina, vol. 1, eds. Fernando Devoto \& Marta Madero. Buenos Aires: Taurus, 1999. 111-45. Print.

Negus, Keith. "The Work of Cultural Intermediaries and the Enduring Distance Between Production and Consumption." Cultural Studies 16. 4 (2002): 501-15. Print.

Nixon, Sean, and Paul Du Gay. "Who Needs Cultural Intermediaries?" Cultural Studies 16.4 (2002): 495-500. Print.

Pereira, Antonio N. Recuerdos de mi tiempo. Montevideo: Imprenta 'El Siglo Ilustrado,' 1891. Print.

Roach, Joseph. Cities of the Dead: Circum-Atlantic Performance. New York: Columbia U P, 1996. Print. 
Ristori, Adelaide. Studies and Memoirs: An Autobiography. Boston: Roberts Brothers, 1888. Print.

Robertson, John Parish, \& William Parish Robertson. Letters on South America: Comprising Travels on the Banks of the Paraná and the Río de la Plata, vol. 3. London: John Murray, 1843. Print.

Rojas, María A. "El público asistente a los circos, hasta la aparición de 'Juan Moreira." Revista de Estudios de Teatro 3 (1960): 50-58. Print.

Rosselli, John. "The Opera Business and the Italian Immigrant Community in Latin America 1820-1930: The Example of Buenos Aires." Past \& Present 127 (1990): 155-82. Print.

Salgado, Susana. The Teatro Solís: 150 Years of Opera, Concert, and Ballet in Montevideo. Middletown: Wesleyan U P, 2003. Print.

Sarmiento, Domingo Faustino. "El teatro como elemento de cultura." Boletín de Estudios de Teatro 1.1 (1943): 3-5. Print.

Seibel, Beatriz. Historia del circo. Buenos Aires: Ediciones del Sol, 2005. Print.

Selgas, José. Hojas sueltas y más hojas sueltas. Madrid: Imprenta de A. Pérez Dubrull, 1883. Print.

Silva, Hernán Asdrúbal, et al. "Estadísticas sobre la inmigración a la Argentina." Inmigración y estadísticas en el cono sur de América. Ed. Hernán Asdrúbal Silva. México, D.F.: Instituto Panamericano de Geografía e Historia; Washington, D.C.: Organización de los Estados Americanos, 1990, 13-68. Print.

The Standard (Buenos Aires).

Turner, Victor. From Ritual to Theater: The Human Seriousness of Play. New York: PAJ Publications, 1982. Print.

Vicuña Mackenna, Benjamín. La Argentina en el año 1855. Prolog.V. Lillo Catalán. Buenos Aires: La Revista Americana de Buenos Aires, 1936. Print.

Wilde, José Antonio. Buenos Aires desde setenta años atrás (1810-1880). Buenos Aires: EUDEBA, 1960. Print. 